\title{
ARTVİN İLİNDE NÜFUSUN BAŞLICA ÖZELLİKLERİ
}

Main Features of the Population in the City of Artvin

Prof. Dr. Hayati DOĞANAY*

Araş. Gör. Fatih ORHAN**

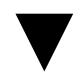

Özet

Geçmişte daha çok sayısal açıdan ön planda tutulan nüfus, günümüzde hem nicel hem de nitel yapısı ile ilgi odă̆ olmaktadır. Bazl karakteristik özellikleri ile dikkat çeken Artvin il nüfusunun incelenmesi de, bu kapsamda gerçekleştirilmeye çalışılmıştır. Sahada gerek Cumhuriyet öncesi ve gerekse Cumhuriyet döneminde yaşanan göçler, ilin demografik yapısı üzerinde belirgin bir şekilde etkili olmaktadır. Bu bağlamda, 2012'de en az nüfusa sahip 6. il olma özelliğine sahip olan Artvin; aynı zamanda yaşlı nüfus oranının en yüksek olduğu ilk beş il arasında da yer almıştır. Bununla birlikte, nüfusun büyük çoğunluğunun klyı kesimleri ile vadi içlerinde toplandı̆̆ ilde, coğrafi koşulların demografik yapı üzerindeki etkisi de önemli oranda hissedilmektedir.

Anahtar Kelimeler: Nüfus, Artvin, nüfus artışı, nüfusun dă̆ılışı, göç.

\section{Abstract}

Population, which was mostly prioritized numerically, is under the spotlight both in terms of quality and quantity today. Analysis of Artvin city population, which attracts attention with some characteristic features, is attempted to be carried out in this frame. Migrations in the area, before and after Republic, have been significantly effective on the demographic structure of the city. In this context, Artvin was the $6^{\text {th }}$ city which had the least population in 2012; the city was also among the first five cities that had the highest aged population. Besides that, the effect of geographic conditions on demographic structure is significantly felt in the city in which most of the population lives in coastal regions and inside the valley.

Key Words: Population, Artvin, population growth, distribution of the population, migration.

\footnotetext{
*Atatürk Üniversitesi, Kâzım Karabekir Eğitim Fakültesi, Ortaöğretim Sosyal Alanlar Eğitimi Bölümü, Coğrafya Eğitimi Anabilim Dalı (e-posta: hdoganay@atauni.edu.tr).

** Atatürk Üniversitesi Eğitim Bilimleri Enstitüsü, Ortaöğretim Sosyal Alanlar Eğitimi Anabilim Dalı, Coğrafya Öğretmenliği Bilim Dalı (e-posta: fatih.orhan@atauni.edu.tr).
} 


\section{Giris}

Nüfus, gerek çevreye ve gerekse gelişmişliğe etkisi açısından üzerinde önemle durulması gereken bir olgudur. Nitekim herhangi bir sahada, insanın çevre üzerindeki etki derecesi, öncelikle nüfus miktarı ve yoğunluğuna bağlı olmakla beraber; nüfusun ekonomik, kültürel ve teknik seviyesi de bu açıdan önemlidir (Tanoğlu, 1969: 29). Ayrıca bir yerin ekonomik, sosyal ve siyasal gelişmişliğinde de, nüfusun nicel ve nitel yapısının rol oynadığı bilinmektedir (Geniş bilgi için bakınız: Doğanay, Özdemir ve Şahin, 2011: 2764). Bütün bunlara ek olarak, bir bölgede bulunan nüfus miktarı ile nüfusun dağılışı ve yoğunluğu, cinsiyet ve yaş yapısı, kır-kent bileşimi, artış hızı, bağımlılık oranı ve göç hareketine kaynaklık etme miktarı gibi pek çok özelliği, çevrenin doğal ve beşeri coğrafya özellikleri ile bağlantılıdır. Bu kapsamda, Artvin ilinin nüfus özelliklerinin ortaya konulması, hem sahadaki nüfus-çevre etkileşiminin analizi, hem de sahanın kalkındırılması için yapılması gereken akılcı planlamalar açısından önemli referans kaynağı olacaktır.

Araştırma sahasını teşkil eden Artvin ili, Doğu Karadeniz Bölümü içerisinde, Gürcistan sınırında yer alır. İl idari alanının kuzeyinde Gürcistan toprakları, kuzeybatısında ise Karadeniz bulunurken; saha doğudan Ardahan, güneyden Erzurum ve batıdan da Rize illeri ile komşudur (Şekil 1). Merkezi ile beraber sekiz ilçeden oluşan ilin toplam yüzölçümü, yaklaşık 7.367 km²'dir. 2012'deki 167.082 kişilik nüfusu ile Türkiye genelinde en az nüfusa sahip 6. il olmuştur. Aynı ölçüte göre, 1965 yılında 11. sırada* yer alması, il nüfusunun niceliksel gelişim açısından ülke ortalamasının altında kaldığını göstermektedir. $\mathrm{Bu}$ durum üzerinde ilin sahip olduğu coğrafi özellikler ile tarihi sürecin etkisi olduğu şüphesizdir.

Artvin ili nüfusunu konu edinen bu araştırmanın temel amacı, demografik açıdan çeşitli özellikleri ile ekstrem noktalarda yer alan il nüfusunun başlıca özelliklerini ortaya koymak ve yapılacak yatırımlarda akılcı planlamaların hazırlanması ve uygulanmasına katkıda bulunmaktır. Bu kapsamda, öncelikle Cumhuriyet dönemini konu edinen bu çalışmada, nüfusun tarihsel değişimini de ortaya koyabilmek açısından, Cumhuriyet dönemi öncesi nüfus özelliklerine de genel hatları ile değinilmiştir. Söz konusu dönemle ilgili bilgiler vilayet salnameleri ile tarihçilerin yaptığı çalışmalardan derlenmiş; Cumhuriyet dönemi ile ilgili veriler ise; TÜIK tarafından hazırlanan istatistiki kaynaklardan elde edilmiştir. Bunlar harita, tablo ve grafik haline dönüştürülerek görselleştirilmiş ve coğrafi bakış açısı ile çeşitli yorumlamalarda bulunulmuştur.

\section{Nüfusun Tarihsel Gelişimi}

Artvin ili arazisi, geçmişten beri birçok devlet ve medeniyete ev sahipliği yapmış olup, bu nedenle de idari açıdan farklı düzenlemelere tabi tutulmuştur. Belirtilen hakikat, ilin tarihsel süreç içerisindeki nüfus gelişimini ortaya koymayı güçleştirmektedir. Özellikle Cumhuriyet öncesi için pek mümkün olmayan süreç, Cumhuriyet döneminde yapılan periyodik nüfus sayımları sayesinde nispeten olanak bulmaktadır. Ancak söz konusu dönemde de; ilin isminde, merkezinde, ilçe sayılarında ve sınırlarında çeşitli değişiklikler

\footnotetext{
" Üstelik günümüzde daha az nüfusa sahip olan Bayburt, Ardahan ve Kilis illeri, o dönemde ilçe statüsünde idi.
} 
yapılmıştır. Bununla birlikte biz çalışmamızda, ilin günümüzdeki idari yapısı ve sınırlarını dikkate alarak, nüfus miktarını belirlemeye çalıştık.

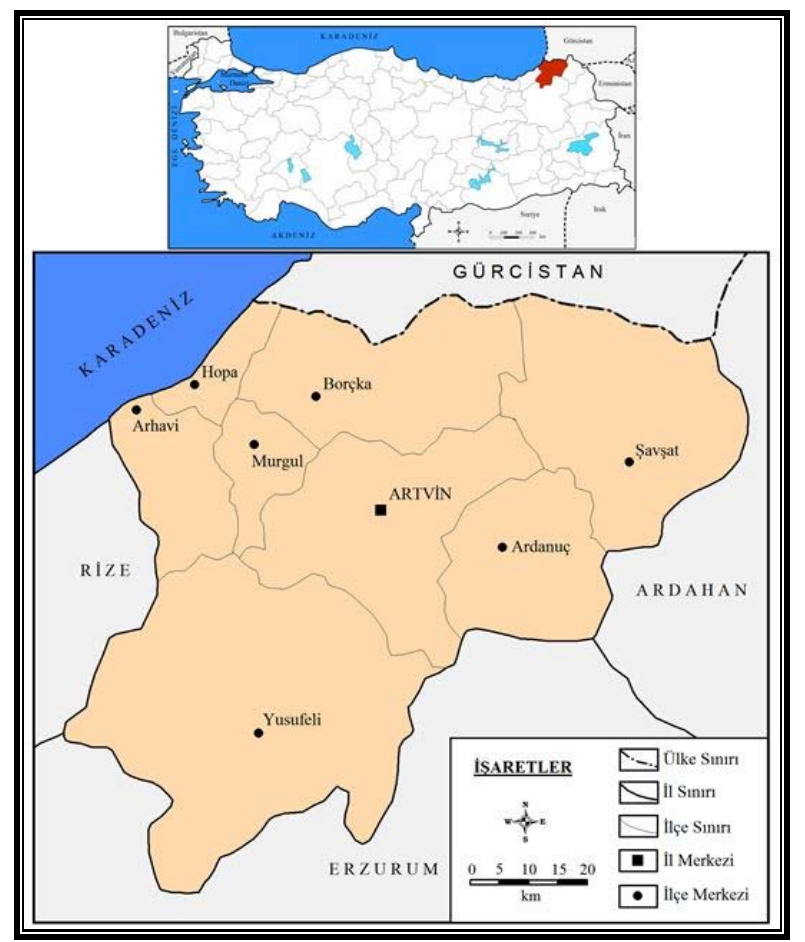

Şekil 1: Artvin ilinin lokasyon haritası.

Sahanın Cumhuriyet dönemi öncesi nüfus gelişimini ele almadan önce, bu dönemdeki idari yapıya kısaca değinmek faydalı olacaktır. XI. yüzyılda Selçuklu hâkimiyeti ile tanışan Artvin ve çevresi, XVI. yüzyllda da Osmanlı egemenliği altına girmişti. Söz konusu dönemde Artvin ve Yusufeli topraklarını içine alan Livane Sancağı kurularak, Erzurum Beylerbeyliğine bağlanmıştır. 1579'da ise Çıldır Eyaletinin oluşturulmasından sonra, adı geçen sancak bu eyalete bağlanmış ve Artvin merkez olmuştur (Tuncel, 1991: 420). Yaklaşık aynı dönemde bölgede Ardanuç, Şavşat, Maçakhel ve Pertekrek (Yusufeli civarları) sancaklarının da oluşturulduğu bilinmektedir (Özdemir, 2001: 83-94). 1828-1829 Osmanl1-Rus savaşından sonra Çıldır Eyalet teşkilatının bozulması sonucu; Livane kazâsı, belli devrelerde Trabzon Eyaletinin Batum ve Lazistan sancaklarına bağlandı. Belirtilen dönemde Maçahel nâhiyesi, söz konusu kazâ sınırlarında yer alırken; Arhavi nâhiyesi de, Lazistan Sancağına bağlı Hopa kazâsı (belli devrelerde Hopa nâhiye, Arhavi kazâ da olmuştur) idari alanı içindeydi. Aynı dönemde Erzurum Eyalet teşkilatı içerisinde bulunan Ardanuç kazâsı ve Şavşit nâhiyesi Çıldır Sancağına; Keskim (Yusufeli) nâhiyesi ise, Erzurum Sancağına bağlı idi (Özdemir, 2001: 114-115). 
Araştırma sahasının tarihinde var olan ve bugünkünden oldukça farklı olan idari yapı, aynı yılda tüm yerleşmeler için nüfus verisi bulmayı zorlaştırmaktadır. Ayrıca Livane kazâsı için zikredilen veriler de, günümüz Artvin ilini tam anlamıyla karşılamamaktadır. Bununla birlikte ulaşılabilen veriler, farklı dönemlere ait olsa da, tablo haline dönüştürülmüştür (Tablo 1). Her yerleşme için verilerin bulunduğu 1872 yllında ilin toplam nüfusu, 48.948 olarak belirlenmiştir. Ancak dile getirilen değerin sadece erkek nüfus olduğu ve kadınların da buna yakın bir değer ifade edeceği düşünüldüğünde, sayının 100 bine yaklaşacağı tahmininde bulunmak yanlış olmasa gerekir. 1922 y1lı için elde edilen verilerde ise; Arhavi, Hopa ve Yusufeli haricindeki ilin diğer kesimlerinde 53.405 kişinin yaşadığı belirtilmiştir. Ancak belirtilen sayıya, kadınlar da dâhildir. Bu durumda söz konusu edilen iki yıl arasında; Artvin ili nüfus miktarının azalmış, hiç değilse artmamış olduğu yorumunu yapmak mümkündür. Zira 1877-1878 Osmanlı-Rus Savaşı sonrasında yöreden yoğun bir şekilde göç yaşandığı bilinmektedir. Bahsi geçen dönemde, Artvin ve çevresinden göç edenlerin sayısının kesin olarak belirlenmesi mümkün olmamakla birlikte, Başbakanlık Osmanlı Arşivlerine dayandırılarak on binlerle ifade edilecek rakamlara ulaştığı tahmin edilmektedir (Demirel, 2009: 322).

Tablo 1: Cumhuriyet Dönemi Öncesi Artvin İli Sınırlarındaki Yerleşmelerin Nüfusları.

\begin{tabular}{|l|c|c|c|c|c|c|}
\hline \multicolumn{1}{|c|}{ Yerleşmeler / Yıllar } & $\mathbf{1 5 7 4}$ & $\mathbf{1 8 4 3}$ & $\mathbf{1 8 6 9}$ & $\mathbf{1 8 7 2}$ & $\mathbf{1 8 7 6}$ & $\mathbf{1 9 2 2}$ \\
\hline Merkez (Livane /Livana) Kazâsı & -- & $6-7$ bin & 17942 & 15972 & 16074 & 14209 \\
\hline Ardanuç Nâhiyesi & -- & -- & -- & 5762 & -- & 7809 \\
\hline Arhavi Nâhiyesi & -- & -- & 6521 & 6643 & 7827 & -- \\
\hline Borçka (Maçahel Nâhiyesi) & -- & -- & 2955 & 3955 & 3630 & 6111 \\
\hline Hopa Nâhiyesi & -- & -- & 4496 & 4496 & 3994 & -- \\
\hline Şavşat (Şavşit) Nâhiyesi & -- & -- & -- & 6448 & -- & 25276 \\
\hline Yusufeli (Keskim/Kiskim) Nâhiyesi & 9019 & -- & -- & 5672 & -- & -- \\
\hline Toplam & & & & $\mathbf{4 8 9 4 8}$ & & $\mathbf{5 3 4 0 5}$ \\
\hline
\end{tabular}

Kaynak: Trabzon ve Erzurum Vilayet Salnameleri ile Yusufeli Tarihi (Demirel,2010: 113), Milli Mücadele Döneminde Artvin (Çapa, 2012: 124-125) ve Bir İngiliz Konsolosunun 1846 Yılında Erzurum'dan Kars'a Seyahati (Ersoy, 1964: 242) adlı eserlerden derlenmiştir.

Artvin ilinin nüfusu ile ilgili en sağlıklı bilgiler Cumhuriyet dönemindeki periyodik nüfus sayımları sonucunda elde edilmiştir. Bilindiği üzere; söz konusu sayımlar, nüfusun yıllara göre toplam sayısı, çeşitli nüfus hareketleri, nüfusun sosyal ve ekonomik nitelikleri, kentsel ve kırsal nüfus miktarları gibi nüfusa ilişkin çeşitli özelliklerin tespit edilmesi (Doğanay, 1997: 151) ile bunların başta plânlama olmak üzere pek çok alanda kullanılmasına olanak sağlamaktadır (Zaman ve Coşkun, 2008: 266). Ancak daha önce de vurgulandığı üzere, bu dönemde de ilin idari yapısında önemli değişiklikler meydana gelmiştir. Bunların açıklanmasının, konunun anlaşılması açısından yerinde bir davranış olacağı kuşkusuzdur.

1877-1878 Osmanlı-Rus savaşı neticesinde Rus işgali altına giren araştırma sahası, 43 yıl işgalde kaldıktan sonra, 16 Mart 1921'de imzalanan Moskova Antlaşması'yla tekrar Türkiye topraklarına katılmıştır. Yaklaşık beş ay Ardahan sancağına bağlı kalan Artvin,

* Günümüz Borçka ilçesi idari alanında yer alan köylerin bir kısmı, o dönemki Maçahel Nâhiyesi içerisinde iken; önemli bir kısmı da Livana kazâsı sınırlarında kalmaktadır. 
kendi adıyla yeni bir sancağın kurulmasıyla bu sancağın merkezi olmuştur. 1924 yılında idari teşkilatlanmada yapılan değişiklik ile Artvin sancağı, aynı adı taşıyan vilayete dönüştürülmüştür. Söz konusu yılda Şavşat, Ardanuç, Borçka ve Murgul (o zamanki idari statüleri ile) bu vilayetin sınırları içerisinde yer almaktadır. 1926 yılında ise Erzurum'dan ayrılıp Artvin'e katılan Yusufeli, 1933 yılında Artvin vilayetinin lağvedilip, ilçe olarak Rize merkezli Çoruh vilayetine bağlanması ile tekrar Erzurum sınırlarına dâhil edilmiştir (Gök, 2010: 47). Ancak 1936 yllında Rize ile Çoruh vilayetleri birbirinden ayrılarak, Artvin merkezli yeni bir Çoruh vilayeti kurulması sonucu, Yusufeli ve Hopa ( Arhavi ve Fındıklı/Viçe nâhiyeleri ile beraber) adı geçen vilayetin ilçeleri haline dönüştürülmüștür. Bununla birlikte Hopa ilçesine bağlı olan Fındıklı, 1948 yılında ilçe statüsüne kavuşmasına rağmen, 1953 yılına kadar, Çoruh vilayetine bağlı kalmıştır. Adı geçen yılda Fındıklı'nın Rize'ye katılması sonucu, bugünkü sınırlar oluşmuștur. Ancak bunların yanı sıra, 1956 yılında ilin adının Artvin olarak değiștirilmesi ile 1954 yılında Arhavi'nin ve 1987 yılında Murgul'un ilçe statüsüne kavuşması gibi birtakım idari değişiklikler de söz konusu olmuştur.

Bilindiği üzere, 1935 yılında yapılan ikinci sayımdan itibaren nüfus sayımları periyodik bir seyir kazanmıştır. 2007 yılından sonra ise, ADNKS (Adrese Dayalı Nüfus Kayıt Sistemi) ile her yıl nüfusumuz hakkında bilgi edinilebilmektedir. Bu kapsamda, Artvin ilinin yapılan ilk sayımdaki (1927) nüfusu, 119.947 olarak belirlenmiştir. 2012 yılına gelindiğinde ise, il nüfusu 167.082'ye ulaşmıştır. Bu durumda; 85 yıllık süreçte il nüfusu, yaklaşık 1.4 kat (\% 39.3) artmıştır. Ancak söz konusu devrede, ülke genelindeki artı̧ın yaklaşı 5.5 kat (\% 454.1) olarak gerçekleştĭgi dikkate alındığında, araştırma sahasındaki büyümenin ne derece düşük seviyede gerçekleştiği anlaşılmış olacaktır (Tablo 2). Bununla birlikte artış sürekli gerçekleşmemiş, bilakis belli dönemlerde nüfus artış hızında olduğu gibi, nüfus miktarında da azalmalar yaşanmıştır.

Tablo 2 incelendiğinde; araştırma sahası nüfusunun iki farklı gelişim seyrine sahip olduğu açıkça görülecektir:

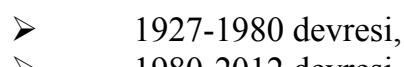

$>\quad 1980-2012$ devresi.

1927-1980 yılları arasını kapsayan birinci devrede, il nüfusunda sürekli artış meydana gelmiştir. Söz konusu devrede, gerçekleşen 109.050 kişilik artış, yarım asırlık bir süreçte nüfusun yaklaşık iki (1.9) katına çıkmasına neden olmuştur. Ayrıca belirtilen periyot arasındaki yıllık nüfus artış hızının seyri, ülke geneliyle paralellik arz eder. Nitekim ülkemizde bu oranın en düşük seviyelerinden birinin gerçekleştiği 1940-1945 dönemi, araştırma sahası için de aynı değeri ifade etmektedir (Tablo 2). Kuşkusuz bu durum üzerinde, I. Dünya ve Kurtuluş savaşları (1914-1922) esnasında doğumların az, ölümlerin fazla gerçekleşmesi sonucu, 1940-1945 döneminde ana-baba olma çağındaki nüfus eksikliğinin yanı sıra, bu yıllarda II. Dünya Savaşının oluşturduğu olumsuz atmosferin etkili olduğu şüphesizdir (Özgür, 98: 12). Türkiye genelinde (\% 30.6) olduğu gibi, Artvin ilinde (\% 22.0) de yıllık nüfus artış hızının en yüksek olduğu dönem, 1955-1960 yılları arasıdır. Söz konusu dönemdeki artışın temel nedeni, birçok bilim adamının ifade ettiği üzere, bir taraftan II. Dünya Savaşı'nın sona ermesi ve dolayısıyla da seferberlik 
Artvin İlinde Nüfusun Başlıca Özellikleri

koşullarının ortadan kalkması sonucu, silahaltına alınan erkeklerin evlerine dönmesiyle evlenmelerin ve doğumların artmış olması iken; diğer taraftan da ekonomik, sosyal ve sağlık alanında başlayan olumlu gelişmelerdir (Doğanay, 1997: 157-158, Tandoğan, 1998: 25-26 ve Özgür, 1998: 13). 1975-1980 döneminde ise, nüfus artışı devam etmekle beraber, yıllık nüfus artış hızı önemli oranda azalmıştır. Söz konusu dönemde ülkede mevcut olan siyasi huzursuzlukların, ili de olumsuz etkilediği tahmin edilmektedir (Tıraş, 1997: 166).

Tablo 2: Sayım Dönemlerine Göre Artvin İli ve Türkiye Geneli Nüfus ve Nüfus Artış Hızları.

\begin{tabular}{|c|c|c|c|c|}
\hline Yıllar & Artvin İli Nüfusu* & $\begin{array}{c}\text { Yılık Nüfus Artış Hızı } \\
(\%)\end{array}$ & Türkiye Nüfusu & $\begin{array}{c}\text { Yıllık Nüfus Artış Hızı } \\
\text { (\%o) }\end{array}$ \\
\hline $\mathbf{1 9 2 7}$ & $119.947^{* *}$ & -- & 13.648 .270 & -- \\
\hline $\mathbf{1 9 3 5}$ & 132.895 & 13.4 & 16.158 .018 & 22.9 \\
\hline $\mathbf{1 9 4 0}$ & 142.669 & 14.7 & 17.820 .950 & 20.5 \\
\hline $\mathbf{1 9 4 5}$ & 148.935 & 8.7 & 18.790 .174 & 10.8 \\
\hline $\mathbf{1 9 5 0}$ & 163.717 & 19.8 & 20.947 .188 & 22.9 \\
\hline $\mathbf{1 9 5 5}$ & 176.845 & 16.0 & 24.064 .763 & 29.7 \\
\hline $\mathbf{1 9 6 0}$ & 196.301 & 22.0 & 27.754 .820 & 26.6 \\
\hline $\mathbf{1 9 6 5}$ & 210.065 & 14.0 & 31.391 .421 & 26.8 \\
\hline $\mathbf{1 9 7 0}$ & 225.869 & 15.0 & 35.605 .176 & 26.6 \\
\hline $\mathbf{1 9 7 5}$ & 228.026 & 1.9 & 40.347 .719 & 21.7 \\
\hline $\mathbf{1 9 8 0}$ & 228.997 & 0.8 & 44.736 .957 & 26.4 \\
\hline $\mathbf{1 9 8 5}$ & 226.338 & -2.3 & 50.664 .458 & 22.9 \\
\hline $\mathbf{1 9 9 0}$ & 212.833 & -11.9 & 56.473 .035 & 20.0 \\
\hline $\mathbf{2 0 0 0}$ & 191.934 & -9.8 & 67.803 .927 & 5.8 \\
\hline $\mathbf{2 0 0 7}$ & 168.092 & -17.7 & 70.586 .256 & 14.2 \\
\hline $\mathbf{2 0 1 2}$ & 167.082 & -1.2 & 75.627 .384 & \\
\hline
\end{tabular}

Kaynak: TÜİK Nüfus Sayımları (1927-2012).

İkinci devre olarak nitelendirdiğimiz 1980-2012 yılları arası ise; Artvin il nüfusunun azaldığı bir dönem olarak dikkati çekmektedir. Zira 1970 yılından itibaren azalmaya başlayan yıllık nüfus artış hızı, 1980 yılından sonra negatif değerler göstermeye başlamıştır. Adı geçen yılda 228.997 olan il nüfusu, 32 yıl içerisinde 61.915 kişi azalarak 167.082' ye gerilemiştir (Şekil 2). Bu durumu, sadece doğal nüfus artış hızının azalması ile açıklamak mümkün değildir. Bununla birlikte, son yıllarda ülke genelinde de, nüfus artış hızında azalmaların meydana geldiği göz önüne alındığında; genel anlamda gelişmişlik seviyesindeki yükselmenin etkisi akla gelse bile, araştırma sahası için daha çok göçler böyle bir tablonun karşımıza çıkmasını sağlamıştır.

\section{Nüfusun Dağılışı}

Artvin ilinde nüfusun dağılışında, belirgin farklılıklar dikkat çekmektedir. $\mathrm{Bu}$ amaçla hazırlanan Şekil 3'ün incelenmesi ile de görülebileceği üzere, yoğun ve seyrek nüfuslu yerler belirgin bir şekilde ayırt edilebilmektedir. Bu durum, temelde coğrafi çevre koşulları ile ilgilidir. Nitekim iklim, su kaynakları, bitki örtüsü, toprak verimliliği, yeryüzü şekilleri ve yükselti gibi doğal çevre faktörlerinin yanı sıra, tarihi olaylar ve idari yapı ile

\footnotetext{
* Nüfus değerleri, ilin günümüz idari yapısı dikkate alınarak hesaplanmıştır.

** Bu sayıya Fındıklı (Viçe) nâhiyesinin nüfusu da dâhildir.
} 
bizzat insan ve onun eseri olan beşeri ve ekonomik faaliyetlerin nüfusun dağılışı üzerinde önemli rol oynadığı birçok coğrafyacı tarafından ifade edilmiştir (Tanoğlu, 1969: 74-78 ve Doğanay, 1997: 217-231). Araştırma sahasındaki nüfusun dağılışında da, bu ve benzeri faktörlerin müşterek rol oynadığını söylemek yanlış olmasa gerekir.

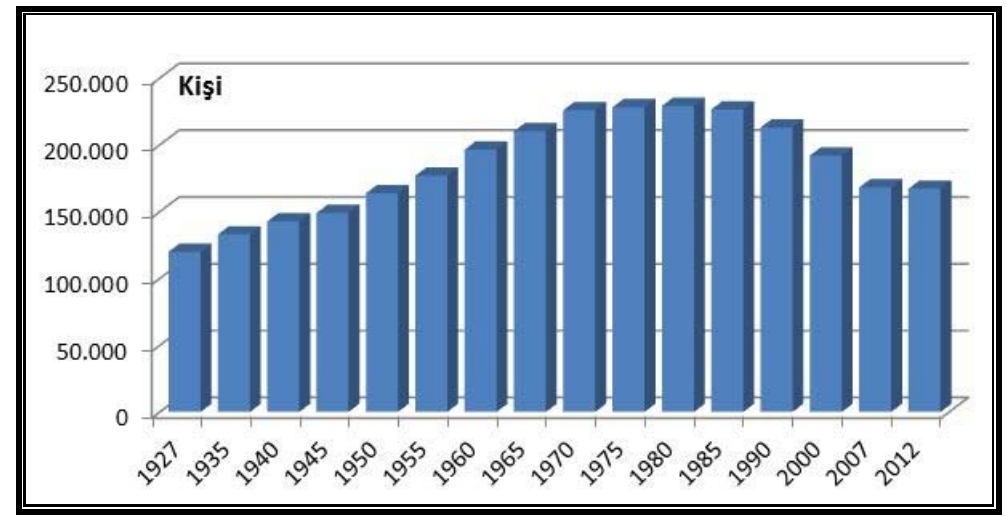

Şekil 2: Artvin il nüfusunun 1927-2012 yılları arasındaki seyri.

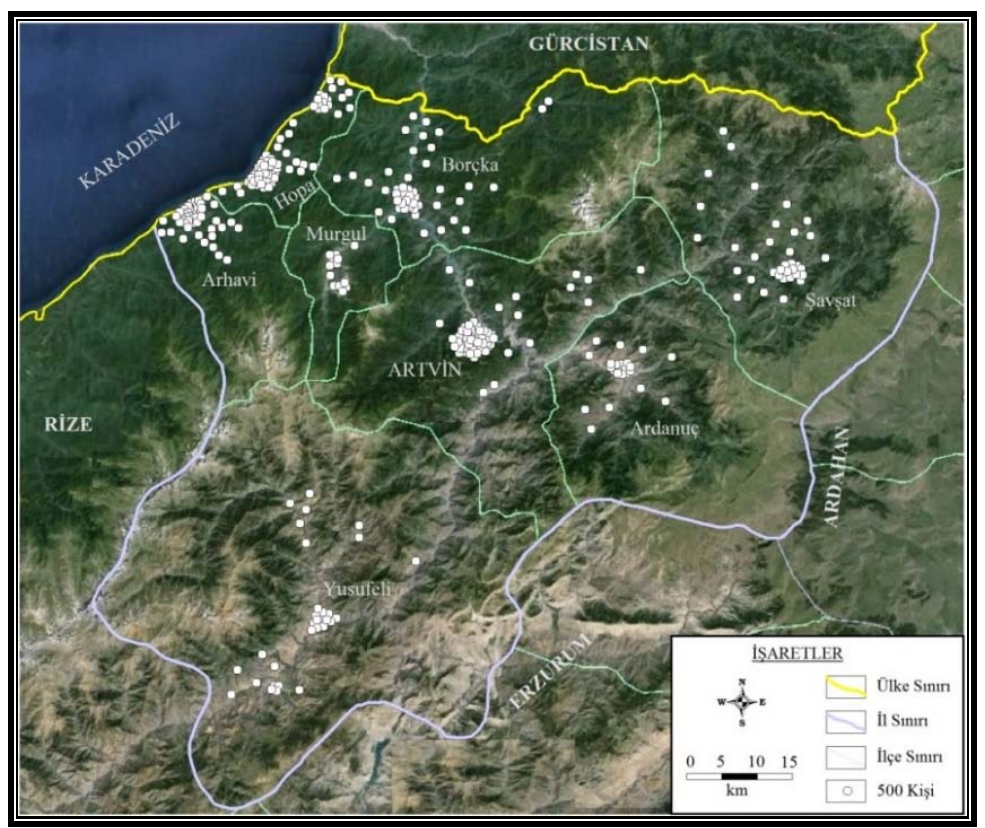

Şekil 3: Artvin ili nüfus dağılış haritası (2012). ${ }^{*}$

* Google Earth harita tabanı kullanılarak hazırlanmıştır. 
Sahada nüfus dağılışını belirleyen faktörlerin başında yeryüzü şekilleri gelir. Artvin ili arazisi, genel olarak Doğu Karadeniz Dağlık Kuşağı içerisinde yer almakta olup, bu kuşağı oluşturan kıyı ve iç sıradağların birbirine oldukça yaklaşıtı̆ı, hatta kesiştiği alanda bulunmaktadır. Kıyı kuşağı içerisinde yer alan Kaçkar (3937 m) ve Karçal (3415 m) dağları zirveleri, aynı zamanda araştırma sahasının en yüksek yerleridir. İç sıradağlar içerisinde yer alan Yalnızçam, Akdağ ve Mescit dağları ise, ilin doğu ve güney sınırlarını teşkil etmektedir. Ayrıca Çoruh Nehri ve kollarının oluşturmuş olduğu akarsu şebekesi de, araziyi derin vadilerle parçalamıștır. Bu kapsamda, dağlık ve parçalı bir topoğrafik yapıya sahip olan sahada, yerleşim alanlarının dağılışında dağlar ve vadi sistemleri önemli bir belirleyici olmuştur. Buna göre, ilde genellikle kıyı kuşağındaki düz alanlar, akarsu vadileri ve bunların yüksek olmayan yamaçlarında yerleşmelerin ve dolayısıyla da nüfusun toplandığı gözlenmektedir. Ancak sahada dağlık alanların tamamıyla nüfustan yoksun alanlar olduğunu düşünmek de yanlış olur. Nitekim, yaylacılık faaliyetleri büyük oranda sürdürülmekte olup, önemli ölçüde bir nüfus bu faaliyetlere katılmaktadır. Bu durumda, ildeki yüksek kesimlerin en azından mevsimlik olarak nüfus barındırdığı söylenebilir.

Karadeniz'e paralel uzanan söz konusu bu dağlar, iklim koşulları açısından da belirgin farklılıklar oluşmasına vesile olmuştur. Özellikle kıyı kuşağı dağların denize bakan yamaçlarında, nemli ve ılıman iklim koşulları görülürken; iç kesimlere doğru bu koşullar tedrici bir şekilde etkisini yitirmektedir. İnsan yaşamına ve çeşitli ekonomik faaliyetlere daha uygun olan bu koşullar nedeniyle, nüfusta kıyı kesiminde toplanma eğilimi meydana gelmiş; iç kesimlerde de benzer iklim şartlarının nispeten hissedildiği vadi içleri, ekseriyetle tercih edilmiştir. İlde görülen bu yöresel iklim farklılıkları; doğal bitki örtüsünün yanı sıra, tarımsal üretim üzerinde de etkili olmaktadır. Bu nedenle de, saha içerisinde çay, kivi, turunçgiller, zeytin, buğday gibi farklı iklim istekleri bulunan tarımsal ürünlerin yetiştirildiğini görmek mümkündür. Bunlardan daha fazla ekonomik değer ifade edenlerin (çay vb.) tarımının yapıldığı alanlar, nüfus açısından da yoğunluk kazanan kesimler olmuştur.

Sahadaki dağların bir diğer etkisi de, ulaşım faaliyetleri üzerinde görülmektedir. Kıyı ile iç kesimler arasındaki ulaşım, ancak akarsu vadileri ve geçitler vasıtasıyla gerçekleşebilmektedir. Bu nedenle de, iç kesimlerde yer alan yerleşmelerin önemli bir kısmı, ulaşım koşullarının elverişli olduğu vadi içlerinde kurulmuştur. Ancak kıyıda yer alan Hopa ve Arhavi ilçeleri, hem karayolu ulaşımı açısından diğerlerine göre avantaja; hem de deniz yolu ulaşımı üstünlüğüne sahiptir. Zira Hopa'da limanın bulunması, bu ilçeye hatta bütün ile ekonomik anlamda canlılık katmaktadır. Ayrıca Karadeniz'in sağladığı avantajlar bunla da sınırlı değildir. Kıyı kesiminde yaşayan ailelerin bir kısmı da geçimini balıkçılıktan sağlamaktadır. Sonuçta, Karadeniz'in beraberinde getirdiği; ekonomik çeşitlilik, ulaşım kolaylığı ve uygun iklim koşulları nedeniyle kıyı kesimleri, nüfusun daha fazla toplandığı ve nüfus yoğunluğunun en yüksek seviyede olduğu alanlar olarak karşımıza çıkmıştır. Bununla birlikte, Hopa ilçesi sınırları içerisinde yer alan ve Gürcistan ile bağlantımızı sağlayan Sarp Sınır Kapısı'nın ticari anlamdaki katkıları da bu noktada etkili olmuştur.

Araştırma sahasındaki nüfus dağglışı üzerinde etkili olan bir diğer faktör de idari yapıdır. Bu kapsamda, idari merkez olan Artvin kenti, birçok açıdan kıyı kuşağındaki 
yerleşmeler kadar avantajlı olmasa da, ilde en fazla nüfus barındıran yerleşme olmuştur (Tablo 3).

Bilindiği gibi, yerleşmeleri kır ve kent yerleşmeleri olarak ikiye ayırıp incelemek mümkündür. Bu ayrımda farklı ölçütler söz konusu olsa da, pek çok bilim adamı tarafından 10.000 nüfus kriteri esas alınmaktadır. Çalışmamızda da, bu yaklaşım ile yapılan sınıflandırmada, dört kent yerleşmesi (Artvin, Hopa, Arhavi ve Borçka) tespit edilmiştir. Buna göre, il nüfusunun yaklaşık \% 42'sinin kentlerde, \% 58'inin ise kırsal yerleşmelerde yaşadığı görülmektedir (Tablo 3).

Tablo 3: Artvin ilindeki kentler ve nüfusları (2012).

\begin{tabular}{|l|c|c|c|c|}
\hline Kentler & Erkek Nüfus & Kadın Nüfus & Toplam Nüfus & $\begin{array}{c}\text { İ Nüfusuna Oranı } \\
(\%)\end{array}$ \\
\hline Artvin & 13.134 & 12.637 & 25.771 & 15.42 \\
\hline Hopa & 9.193 & 9.103 & 18.296 & 10.95 \\
\hline Arhavi & 7.868 & 8.105 & 15.973 & 9.56 \\
\hline Borçka & 5.489 & 5.152 & 10.641 & 6.37 \\
\hline Toplam & 35.684 & 34.997 & 70.681 & 42.30 \\
\hline
\end{tabular}

Kaynak: ADNKS verilerinden derlenmiştir.

Artvin ilinde nüfus yoğunluklarının ilçelere göre dağılımı incelendiğinde; nüfusun dağılışı ile ilgili belirtilen açıklamaları destekleyen bir tablonun karşımıza çıktığı görülmektedir. İl genelinde 22.68 olan aritmetik nüfus yoğunluğu, kuşkusuz yüzölçümü değerlerinin de etkisiyle, kıyı ilçelerinde daha yüksek gerçekleşmiştir. Yoğunluk değerlerinin en yüksek olduğu Hopa (156.26) ilçesini, yine bir kıyı ilçesi olan Arhavi (65.55) takip etmektedir. Merkez ilçenin (31.05) bu açıdan ancak üçüncü sırada yer alabildiği ilde, en geniş alana sahip olan Yusufeli ilçesi (9.79) ise, son sırada bulunmaktadır (Tablo 4).

Tablo 4: Artvin ilindeki nüfus ve nüfus yoğunluklarının ilçelere göre dağılımı (2012).

\begin{tabular}{|l|c|c|c|}
\hline İlçe Adı & Toplam Nüfus & Yüzölçümü $\left.\mathbf{( k m}^{\mathbf{}}\right)$ & Nüfus Yoğunluğu (km² $\mathbf{~} \mathbf{k i s ̧ i )}$ \\
\hline Merkez & 33.692 & 1085 & 31.05 \\
\hline Ardanuç & 11.406 & 989 & 11.53 \\
\hline Arhavi & 19.602 & 299 & 65.55 \\
\hline Borçka & 22.964 & 799 & 28.74 \\
\hline Hopa & 33.129 & 212 & 156.26 \\
\hline Murgul & 6.395 & 336 & 19.03 \\
\hline Şavşat & 17.660 & 1377 & 12.82 \\
\hline Yusufeli & 22.234 & 2270 & 9.79 \\
\hline Toplam & 167.082 & 7367 & 22.68 \\
\hline
\end{tabular}

Kaynak: TÜİK verilerinden yararlanılarak hesaplanmıştır.

\section{Nüfusun Cinsiyet Oranı ve Yaş Yapısı}

Bir bölgedeki nüfusun yaş ve cinsiyet yapısı, demografik öneminin yanı sıra, sosyal ve ekonomik özellikler bakımından da büyük önem taşır (Koca, 2005: 84). Belirli bir nüfus içerisindeki 100 veya 1000 kadın başına düşen erkek sayısı (Doğanay, 1997: 164 ve 
Tümertekin ve Özgüç, 2011: 272) olarak tanımlanan cinsiyet oranının belirlenmesi ve bilinmesi bu açıdan da önem arz etmektedir.

Artvin ilinde, erkek ve kadın nüfusları arasında çok büyük farklılıklar olmamakla birlikte; uzun süren savaşlara bağlı olacak ki, Cumhuriyetin ilk yıllarından itibaren kadın nüfus fazlalığı dikkat çekmektedir. Aradaki en büyük fark 1945 yılında meydana gelmiş olup, adı geçen yılda cinsiyet oranı \% 92.2 olarak gerçekleşmiştir. Bu durumun o yıllarda erkek nüfusun silahaltına alınmasından kaynaklanmış olabileceği kanaatindeyiz. Sahada 1990 yılından sonra ise erkek nüfus oranında artış meydana gelmiştir. Buna bağlı olarak, 2000 ve 2012 yıllarında erkek nüfus fazlalığı görülürken; 2007 yılında sadece 42 kişilik bir farkla kadın nüfus daha fazla olmuştur. Son nüfus sayımı (2012) verilerine göre, Artvin ilinde erkek ve kadın nüfus oranları (erkek \% 50.3, kadın \% 49.7), Türkiye ortalamasıyla (erkek \% 50.2, kadın \% 49.8) neredeyse aynı değerleri göstermiştir (Tablo 5). Belirtilen çerçevede, sahada cinsiyet yapısını büyük oranda değiştirecek olayların meydana gelmediği anlaşılmaktadır. Ancak Artvin ilinin göç veren bir saha olduğu düşünüldüğünde; ilk bakışta çelişki gibi görünen bu durum, göç edenlerin tüm aile bireyleri ile birlikte bahsi geçen faaliyete katılmaları ile açıklanabilir. Nitekim 2012 yılında ilden göç edenler arasında kadınların daha fazla olduğu gerçeği, bu durumu kanıtlamaktadır.

Tablo 5: Artvin ilinde nüfusun cinsiyet yapısı ve oranı (1927-2012).

\begin{tabular}{|c|c|c|c|c|c|}
\hline Yıllar & Erkek Nüfus & Yüzdesi (\%) & Kadın Nüfus & Yüzdesi (\%) & Cinsiyet Oranı (\%) \\
\hline $\mathbf{1 9 2 7}$ & 58.647 & 48.9 & 61.297 & 51.1 & 95.6 \\
\hline $\mathbf{1 9 3 5}$ & 64.348 & 48.4 & 68.547 & 51.6 & 93.8 \\
\hline $\mathbf{1 9 4 0}$ & 69.678 & 48.8 & 72.991 & 51.2 & 95.4 \\
\hline $\mathbf{1 9 4 5}$ & 71.465 & 48.0 & 77.470 & 52.0 & 92.2 \\
\hline $\mathbf{1 9 5 5}$ & 85.677 & 48.5 & 91.168 & 51.5 & 93.9 \\
\hline $\mathbf{1 9 6 0}$ & 96.463 & 49.1 & 99.838 & 50.9 & 96.6 \\
\hline $\mathbf{1 9 6 5}$ & 102.630 & 48.9 & 107.435 & 51.1 & 95.5 \\
\hline $\mathbf{1 9 7 0}$ & 110.613 & 49.0 & 115.256 & 51.0 & 95.9 \\
\hline $\mathbf{1 9 7 5}$ & 113.829 & 49.9 & 114.197 & 50.1 & 99.6 \\
\hline $\mathbf{1 9 8 0}$ & 112.606 & 49.2 & 116.391 & 50.8 & 96.7 \\
\hline $\mathbf{1 9 8 5}$ & 110.557 & 48.8 & 115.781 & 51.2 & 95.4 \\
\hline $\mathbf{1 9 9 0}$ & 104.093 & 48.9 & 108.740 & 51.1 & 95.7 \\
\hline $\mathbf{2 0 0 0}$ & 96.599 & 50.3 & 95.335 & 49.7 & 101.3 \\
\hline $\mathbf{2 0 0 7}$ & 84.025 & 50.0 & 84.067 & 50.0 & 99.9 \\
\hline $\mathbf{2 0 1 2}$ & 84.060 & 50.3 & 83.022 & 49.7 & 101.2 \\
\hline
\end{tabular}

Kaynak: TÜIKK nüfus sayım sonuçlarından derlenmiştir.

Sahadaki cinsiyet yapısını ilçeler bazında ele aldığımızda ise; yine arada büyük farklılıklar olmamakla birlikte; Arhavi ve Yusufeli haricindeki diğer ilçelerde, erkek nüfus fazlalığı görülmektedir. Erkek nüfus oranının en fazla olduğu Murgul ilçesinde ( \% 51.95), burada bulunan bakır madeni işletmesinde çalışan erkek işgücünün bu oranı arttırdığı şüphesizdir (Tablo 6).

Nüfusun en az cinsiyet yapısı kadar önemli olan diğer bir özelliği de, yaş yapısıdır. Her hangi bir yerdeki nüfusun sözü geçen özelliğinin bilinmesi, en başta insanların ihtiyaçlarının, eğilimlerinin ve sosyal işlevlerinin belirlenmesi ve bu yönde uygulanacak politikaların oluşturulması açısından önem arz etmektedir (Işık, 1997: 287). Özellikle 
sosyal ve ekonomik amaçlı planlamalarda, stratejilerin isabetli seçilebilmesi bakımından bu gereklidir Doğanay, 1997: 165). Örneğin, nüfus içindeki çocuk, yetişkin ve yaşlı oranlarının bilinmesi, bunlara yönelik eğitim, istihdam, sağlık ve bakım hizmetlerinin planlanmasında kolaylıklar sağlayacaktır (Özgür, 1998: 76). Bu nedenle de, Artvin il nüfusu hem geniş, hem de dar aralıklı sınıflandırılmaya tabi tutularak, çeşitli çıkarımlarda bulunulmaya çalışılacaktır.

Tablo 6: Artvin ilindeki erkek ve kadın nüfusun ilçelere göre dağılımı (2012).

\begin{tabular}{|l|c|c|c|c|}
\hline İlçe Adı & Erkek Nüfus & Yüzdesi (\%) & Kadın Nüfus & Yüzdesi (\%) \\
\hline Merkez & 17144 & 50.88 & 16548 & 49.12 \\
\hline Ardanuç & 5770 & 50.59 & 5636 & 49.41 \\
\hline Arhavi & 9672 & 49.34 & 9930 & 50.66 \\
\hline Borçka & 11703 & 50.96 & 11261 & 49.04 \\
\hline Hopa & 16595 & 50.09 & 16534 & 49.91 \\
\hline Murgul & 3322 & 51.95 & 3073 & 48.05 \\
\hline Şavşat & 8861 & 50.18 & 8799 & 49.82 \\
\hline Yusufeli & 10993 & 49.44 & 11241 & 50.56 \\
\hline Toplam & 84060 & 50.31 & 83022 & 49.69 \\
\hline
\end{tabular}

Kaynak: ADNKS verilerinden derlenmiştir.

Geniş aralıklı gruplandırmaya göre, Artvin il nüfusunun \% 18.74’ü, 0-14 yaş grubunda yer almaktadır. Ülkemiz genelinde ise, aynı yaş grubunda bulunanların oranı \% 24.94'tür. Bu durum, araştırma sahasındaki çocuk nüfusun ve dolayısıyla da doğum oranlarının düşük olduğunun önemli bir kanıtıdır. İlde, çalışma çağı nüfusu olarak adlandırılan 15-64 yaş aralığındaki kişi sayısı ise 112.587 olup, toplam nüfusun \% 67.38 'ini teşkil etmektedir. Bu oran, ülkemiz genelindeki (\% 67.55) ile neredeyse aynıdır (Tablo 7). Bilindiği üzere, istihdam şartlarının da uygun olması durumunda, bir yerdeki çalışma çağı nüfusunun sayısal ve oransal fazlalığı, o yerin ekonomisi için olumlu sonuçlar ortaya çıkarmaktadır (Doğanay, 1997: 167). Ancak ilde yeterli istihdam alanının bulunmaması, söz konusu yaş grubundaki nüfusun bir kısmının işsiz kalmasına, bir kısmının da göç etmesine neden olmaktadır. Nitekim 2011 yılı verilerine göre; ilde işsizlik oranı \% 6.0 olarak kaydedilmişken, istihdam oranı ise ancak \% 54.7'de kalmıştır (TÜİK, Seçilmiş Göstergelerle Artvin 2012.). Araştırma sahasındaki yaşlı nüfus (65 yaş üstü) oranı ise oldukça yüksektir. Zira Artvin, TÜIKK verilerine (2012) göre, ülke genelinde bu oranın en yüksek olduğu iller sıralamasında beşinci sırada yer almıştır. Türkiye ortalamasının \% 7.51 olduğu bu değer, ilde \% 13.88 olarak gerçekleşmiştir (Tablo 7 ve Şekil 4). Bu durum, bir taraftan hayat standartları ve sağlık alanındaki iyileşmenin; diğer taraftan da ilden göç edenlerin emeklilik çağında memleketlerine geri dönüş yapmalarının bir sonucu olabilir.

Geniş aralıklı gruplandırma, nüfusun bağımlılık oranının hesaplanmasında da kullanılabilir. Çalışma çağı dışındaki nüfusun (0-14 ve 65+), çalışma çağı içerisindeki nüfusa (15-64) oranlanması sonucu elde edilen bu oran, 2012 yılı için Artvin'de \% 48.4 iken, Türkiye genelinde \% 48.0 olarak gerçekleşmiştir. Buna göre, araştırma sahasındaki değerlerin, ülkemiz geneli ile paralellik gösterdiği anlaşılmaktadır. 
Artvin İlinde Nüfusun Başlıca Özellikleri

Tablo 7: Geniş aralıklı yaş gruplandırmasına göre Artvin ili ve Türkiye geneli nüfusları (2012).

\begin{tabular}{|l|c|c|c|c|}
\hline Yaș Grubu & Artvin İli & Yüzdesi (\%) & Türkiye Geneli & Yüzdesi (\%) \\
\hline $\mathbf{0 - 1 4}$ & 31.304 & 18.74 & 18.857 .179 & 24.94 \\
\hline $\mathbf{1 5 - 6 4}$ & 112.587 & 67.38 & 51.088 .202 & 67.55 \\
\hline $\mathbf{6 5}+$ & 23.191 & 13.88 & 5.682 .003 & 7.51 \\
\hline Toplam & 167.082 & 100 & 75.627 .384 & 100 \\
\hline
\end{tabular}

Kaynak: ADNKS verilerinden derlenmiştir.

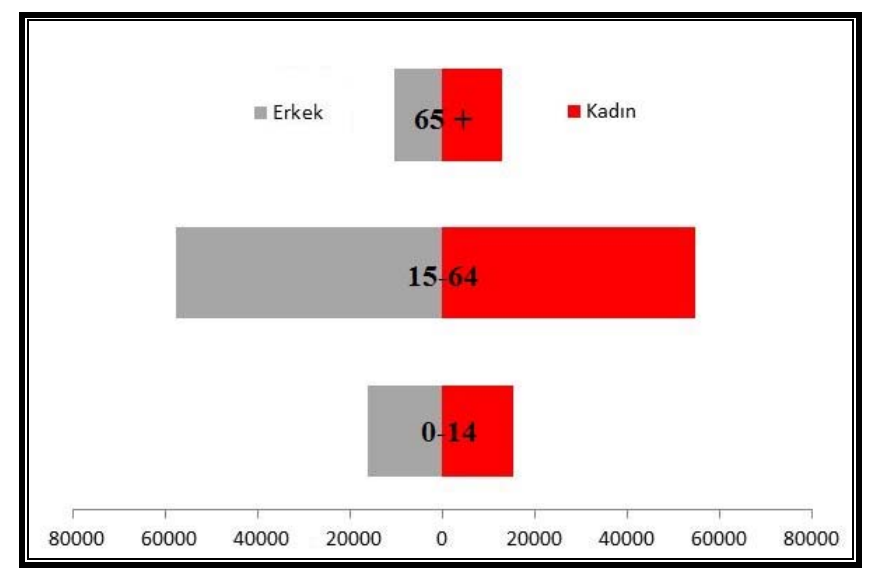

Şekil 4: Artvin ili nüfusunun geniş aralıklı gruplandırmaya göre dağılımı (2012).

İl nüfusunun dar aralıklı yaş gruplandırmasında da, benzer sonuçlar ortaya çıkmakla beraber, oluşan nüfus piramidinin gelişmiş ülkelerin piramidine benzediği dikkat çekmektedir. Buna göre; sahada doğum oranlarının günümüzden 20-25 yıl öncesine göre oldukça hızlı bir şekilde azaldığını, yaşlı nüfus oranında ise bir artma eğiliminin ortaya çıktığını söyleyebiliriz. Ayrıca, ildeki çalışma çağı içerisinde yer alan dinamik nüfus varlığı, yeterli iş imkânlarının sağlanması durumunda, il ekonomisine önemli katkılar sunabilecek potansiyeldedir (Şekil 5).

\section{Göçler}

Birçok bilimin araştırma konuları içerisinde yer alan göç olgusu, özellikle nüfusun dağılışı üzerinde belirleyici olması ile neden ve sonuçları itibariyle coğrafyanın da öncelikli inceleme alanlarından biridir. Nitekim göçler, yerleşmelerin nüfuslarını etkilediği gibi nüfusun demografik yapısında da önemli değişikliklere neden olabilmektedir. Nüfusun; devamlı yaşam bölgelerini kişisel, aileler ve gruplar halinde terk edip, geçici ya da sürekli olarak yaşamak amaciyla bir başka yere gitmesi (Doğanay, 1997: 172-173) şeklinde tanımlanabilecek olan göç; bir taraftan nedenleri, diğer taraftan da hem göç alan, hem de göç veren bölgelerdeki sonuçları itibariyle önemle üzerinde durulması gereken bir olgudur.

Bilindiği üzere, Karadeniz bölgesi ve özellikle de Doğu Karadeniz bölümü, ülkemizin en fazla göç veren yerleri arasında olagelmiştir (Doğanay, 1986: 281). Araştırma 
sahamızı teşkil eden Artvin ili de, bulunduğu bölge ile aynı kaderi paylaşmakta olup, göç veren yerleşmeler arasında kendisine yer bulmuştur. Ancak bu ifadeden, ilin hiç göç almadığı gibi yanlış bir kanıya kapılmamak gerekir. Zira Artvin ili, her dönemde göç alıyor olmakla birlikte, verdiği göç daha fazla gerçekleşmekte; bir başka deyişle, net göç negatif değerler göstermektedir. Örneğin aradaki farkın en fazla olduğu 1985-1990 devresinde; 32.713 kişi Artvin'den ülkemizin değişik yerlerine göç etmişken, 12.341 kişi de göç yoluyla ile gelmiş idi. Yani, söz konusu devrede yaşanan net göç -20.372 iken, net göç hızı da \%o -98.6 olarak karşımıza çıkmıştır. 2007-2012 devresinde ise; 39.755 kişi Artvin'den göç etmişken; ilin aldığı göç miktarı da 35.255 kişidir. Buna göre, adı geçen devrede yaşanan net göç -4.500 , net göç hızı da \%o -27.3 olmuştur. Yıllık değerler dikkate alındığında ise, 2010-2011 yılları arasında, ilin aldığı ve verdiği göç miktarları eşitlenmiş ve net göç hızı da sıfır olarak gerçekleşmiştir. Tablo 8'in incelenmesi ile de görülebileceği üzere, Artvin ilinin dışarıya verdiği göç miktarında azalma olmamışsa da, aldığı göç miktarında önemli oranda artış meydana geldiği açıkça ortadadır. Bu durum bize, ekonomik ve sosyal kısıtlılıklar nedeniyle ilden yaşanan göçlerin hâlâ devam ettiğini, ancak eskiden göç etmiş olanların da özellikle emekli olduktan sonra memleketlerine geri dönüş yaptığını kanıtlamaktadır. Bütün bunlara ek olarak Artvin, 1995-2000 devresinde net göç hızına göre yapılan sıralamada en fazla göç veren 8. il iken (TÜIK, 2005: 48-49), 2011-2012 yılları arasında 39. sırada yer almıştır. $\mathrm{Bu}$ istatistiki veriler, araştırma sahasındaki net göç miktarının, hâlâ negatif değerler göstermekle beraber, giderek azaldığı gerçeğini ortaya koymuştur.

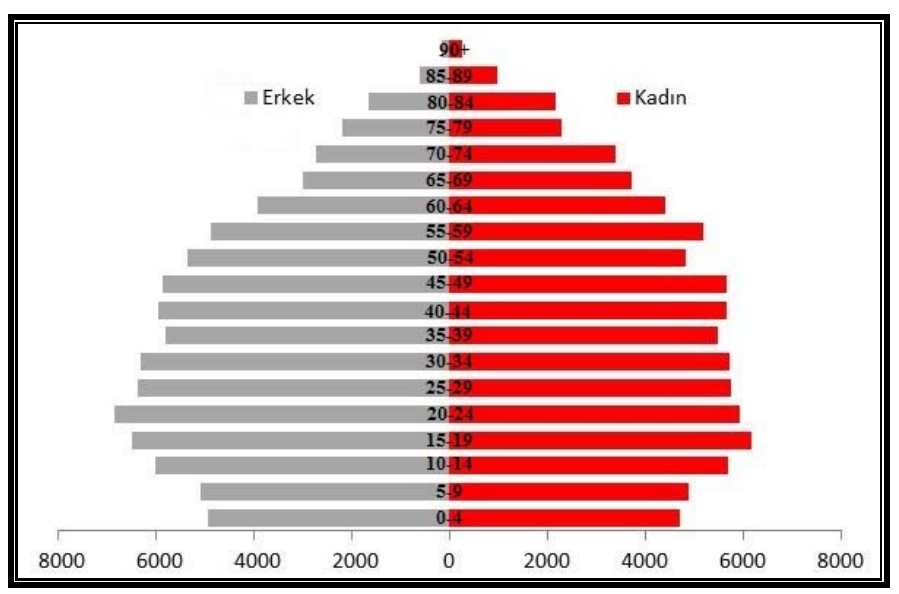

Şekil 5: Artvin ili nüfusunun dar aralıklı gruplandırmaya göre dağılımı (2012).

Eldeki veriler 1şı̆̆ında, Cumhuriyet tarihi boyunca ilden yaşanan göçleri dâhi tam olarak ortaya koymak oldukça güçtür. Ancak diğer illerde yaşayan Artvin ili nüfusuna kayıtlı olanlar, bu konuda bize fikir verebilir. Buna göre, araştırma sahası sınırları dışında ikamet eden 279.243 kişi, Artvin ili nüfusuna kayıtlıdır. Bunların yaklaşık \% 72'si (\%71.63), dört büyükşehirde (İstanbul, Bursa, Ankara ve Kocaeli) toplanmıştır (Şekil 6). Bunlardan ilk sırada gelen İstanbul'da yaşayan Artvinlilerin il nüfusuna oranı, \% 50’ye 
yaklaşmıştır. Buna ikinci sırada gelen Bursa da eklendiğinde, bu oran \% 86.5'e yükselmektedir. Bu çerçevede genel olarak bakıldığında, araştırma sahası dışında yaşayan Artvinlilerin, il nüfusunun neredeyse iki katına (1.7) denk geldiği görülecektir (Tablo 9). Ayrıca, ilden yurt dışına göç etmiş olanlarla ilgili 2012 yılı için elde veri bulunmamaktadır. Bununla birlikte, TÜiK verilerine göre, 2000 yılında doğum yeri Artvin olan 1.178 kişi yurt dışında ikamet etmekte idi (DİE, 2001: 82). Bu sayıya daha önce göç etmiş ailelerin, gittikleri ülkede doğan çocukları da eklendiğinde önemli bir yekûn tutacağı aşikârdır.

Tablo 8: Artvin ilinin yıllara göre aldığı ve verdiği göç miktarları ile hızları (1975-2012).

\begin{tabular}{|l|c|c|c|c|}
\hline Yıllar & Aldığı Göç & Verdiği Göç & Net Göç & Net Göç Hızı (\%o) \\
\hline $\mathbf{1 9 7 5 - 1 9 8 0}$ & 10.472 & 23.159 & -12.687 & $-61,2$ \\
\hline $\mathbf{1 9 8 0 - 1 9 8 5}$ & 12.276 & 23.131 & -10.855 & -51.1 \\
\hline $\mathbf{1 9 8 5 - 1 9 9 0}$ & 12.341 & 32.713 & -20.372 & -98.6 \\
\hline $\mathbf{1 9 9 5 - 2 0 0 0}$ & 14.374 & 25.934 & -11.560 & -63.6 \\
\hline $\mathbf{2 0 0 7 - 2 0 1 2}$ & 35.255 & 39.755 & -4500 & -27.3 \\
\hline $\mathbf{2 0 0 7 - 2 0 0 8}$ & 6.700 & 8.660 & -1.960 & -11.7 \\
\hline $\mathbf{2 0 0 8 - 2 0 0 9}$ & 6.206 & 7.547 & -1.341 & -8.1 \\
\hline $\mathbf{2 0 0 9 - 2 0 1 0}$ & 7.115 & 7.988 & -873 & -5.3 \\
\hline $\mathbf{2 0 1 0 - 2 0 1 1}$ & 7.948 & 7.948 & 0 & 0.0 \\
\hline $\mathbf{2 0 1 1 - 2 0 1 2}$ & 7.286 & 7.612 & -326 & -1.9 \\
\hline
\end{tabular}

Kaynak: TÜİK göç istatistikleri ile ADNKS verilerinden derlenmiştir.

Tablo 9: Artvin nüfusuna kayıtlı olanların illere göre dağılımı (2012).

\begin{tabular}{|l|c|c|c|}
\hline İller & Nüfus Miktarı & $\begin{array}{c}\text { Artvin İl Nüfusuna (2012) } \\
\text { Oranı }\end{array}$ & $\begin{array}{c}\text { Artvin Dışında Yaşayan Nüfusa } \\
\text { Oranı }\end{array}$ \\
\hline İstanbul & 81.862 & 48.99 & 29.31 \\
\hline Bursa & 62.750 & 37.56 & 22.47 \\
\hline Ankara & 31.444 & 18.82 & 11.26 \\
\hline Kocaeli & 23.997 & 14.36 & 8.59 \\
\hline İzmir & 10.877 & 6.51 & 3.89 \\
\hline Samsun & 8.052 & 4.82 & 2.88 \\
\hline Rize & 7.480 & 4.48 & 2.68 \\
\hline Sakarya & 5.733 & 3.43 & 2.05 \\
\hline Toplam & 232.195 & 138.97 & 83.15 \\
\hline Diğer İller & 47.048 & 28.16 & 16.85 \\
\hline Genel Toplam & $\mathbf{2 7 9 . 2 4 3}$ & 167.13 & 100 \\
\hline
\end{tabular}

Kaynak: ADNKS verilerinden derlenmiştir.

Sahadaki göçler, daimi ikametgâh ölçütü esas alınarak da, belli bir sınıflandırmaya tabi tutulabilir. Bu kapsamda, 2011-2012 yılları arasında ilden dışarıya olan göçler ile Artvin'e yaşanan göçler ele alınmıştır. Söz konusu dönemde, toplamda 7612 olan sahadan göç edenlerin dağılımına bakıldığında; Artvin nüfusuna kayıtlı olanların dağı̆lımı ile paralellik gösterdiği dikkat çekmektedir. Zira o sınıflandırmada ilk dört sırada yer alan iller, burada da ilk beşe girebilmişlerdir. Sıralamada ilk iki sıra değişmemekle beraber, üçüncü sırayı sınır komşusu olan Rize ili almıştır. Genel olarak ele alındığında ise; ilden yaşanan göçlerin genel çekim merkezleri olan büyükşehirler (İstanbul, Bursa, Ankara, Kocaeli ve

\footnotetext{
* Bu döneme ait net göç hızının hesaplamasında kullanılan formül için bakınız: Özgür, 2010: 55-56.
} 
İzmir) ile bölgesel çekim merkezlerine (Rize, Trabzon, Samsun, Erzurum gibi) yöneldiği görülmektedir (Tablo 10 ve Şekil 7). Ayrıca bu yerlerin, 1877-1878 Osmanlı-Rus savaşından sonra, Artvin'den göç eden 93 muhacirlerinin en fazla yerleştirildiği iller olması (Demirel, 2009: 323), bu durumun da göç edilen yerlerin seçiminde önemli bir etken olabileceği izlenimini ortaya çıkarmaktadır.

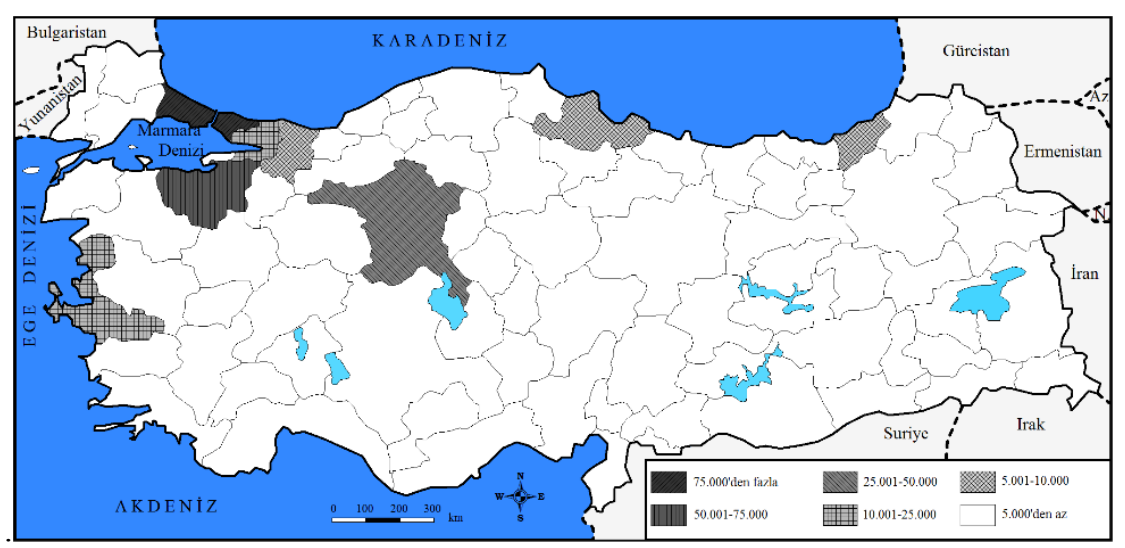

Şekil 6: Artvin nüfusuna kayıtlı olanların illere göre dağılımı (2012).

Araştırma sahasındaki göç olgusu ile ilgili en dikkat çekici özellik, en fazla göç verdiği ve aldığı illerin tamamıyla aynı olmasıdır (Tablo 10 ve Şekil 8). Sıralamada bile ancak ufak tefek farklılıkların olması, daha önce göç verdiği bölgelere hâlâ göçün devam etmekle beraber, buralardan geri dönüşlerin de yaşandığının önemli bir kanıtı niteliğindedir. Özellikle İstanbul ve Ankara gibi ülkemizin en büyük kentlerine verdiği göç miktarının, bu illerden aldığı göç miktarından daha düşük olması, bu bakımdan oldukça manidardır

Tablo 10: Artvin ilinden göç eden ve göç yoluyla ile gelen nüfusun dağılımı (2012).

\begin{tabular}{|l|c|c|l|c|c|}
\hline \multicolumn{2}{|c|}{$\begin{array}{c}\text { Artvin İlinden Göç Eden Nüfusun } \\
\text { İllere Göre Dağılımı }\end{array}$} & \multicolumn{3}{c|}{$\begin{array}{c}\text { Artvin İline Göç Eden Nüfusun } \\
\text { Illere Göre Dağılımı }\end{array}$} \\
\hline İlin Adı & $\begin{array}{c}\text { Göç Eden } \\
\text { Nüfus }\end{array}$ & $\begin{array}{c}\text { Yüzdesi } \\
(\%)\end{array}$ & İlin Adı & $\begin{array}{c}\text { Göç Eden } \\
\text { Nüfus }\end{array}$ & $\begin{array}{c}\text { Yüzdesi } \\
(\%)\end{array}$ \\
\hline İstanbul & 1.194 & 15.69 & İstanbul & 1.226 & 16.83 \\
\hline Bursa & 892 & 11.72 & Bursa & 665 & 9.13 \\
\hline Rize & 687 & 9.02 & Ankara & 646 & 8.87 \\
\hline Ankara & 608 & 7.99 & Rize & 553 & 7.59 \\
\hline Kocaeli & 423 & 5.56 & Samsun & 342 & 4.69 \\
\hline Trabzon & 388 & 5.10 & Kocaeli & 320 & 4.39 \\
\hline Samsun & 301 & 3.95 & Trabzon & 310 & 4.25 \\
\hline Erzurum & 285 & 3.74 & Erzurum & 274 & 3.76 \\
\hline İzmir & 224 & 2.94 & İzmir & 241 & 3.31 \\
\hline Toplam & 5002 & 65.71 & Toplam & 4577 & 62.82 \\
\hline Diğer İller & 2610 & 34.29 & Diğer İller & 2709 & 37.18 \\
\hline Genel Toplam & 7612 & 100 & Genel Toplam & 7286 & 100 \\
\hline
\end{tabular}

Kaynak: ADNKS verilerinden derlenmiştir. 
Artvin İlinde Nüfusun Başlıca Özellikleri

Araştırma sahasındaki göç hareketliliği, cinsiyet ve yaş yapısına göre incelendiğinde de bazı sonuçlara ulaşmak mümkündür. Aradaki fark çok büyük olmamakla birlikte, Artvin'in aldığı göçlerde erkek, verdiği göçlerde ise kadın fazlalı̆̆ çıkmıştır. Bu durum, günümüz şartlarında artık göçlerin tüm aile bireylerini kapsayan bir niteliğe dönüşmesinin bir sonucu olarak düşünülebilir. Artvin ilinin aldığ1 ve verdiği göçler yaş yapısına göre karşılaştırıldığında ise; en büyük farkın 50 yaş üstü grupta meydana geldiği görülmektedir. İl dışına göç edenlerin \% 13.7'si, söz konusu yaş grubunda yer alırken; bu oran, göç yoluyla ile gelenlerde \% 17.9 olarak gerçekleşmiştir (Tablo 11). Karşımıza çıkan bu tablo, çalışmak üzere göç etmiş olan ailelerin bir kısmının, emeklilik dönemlerinde memleketlerine geri dönüş yaptığı varsayımını doğrulamaktadır.

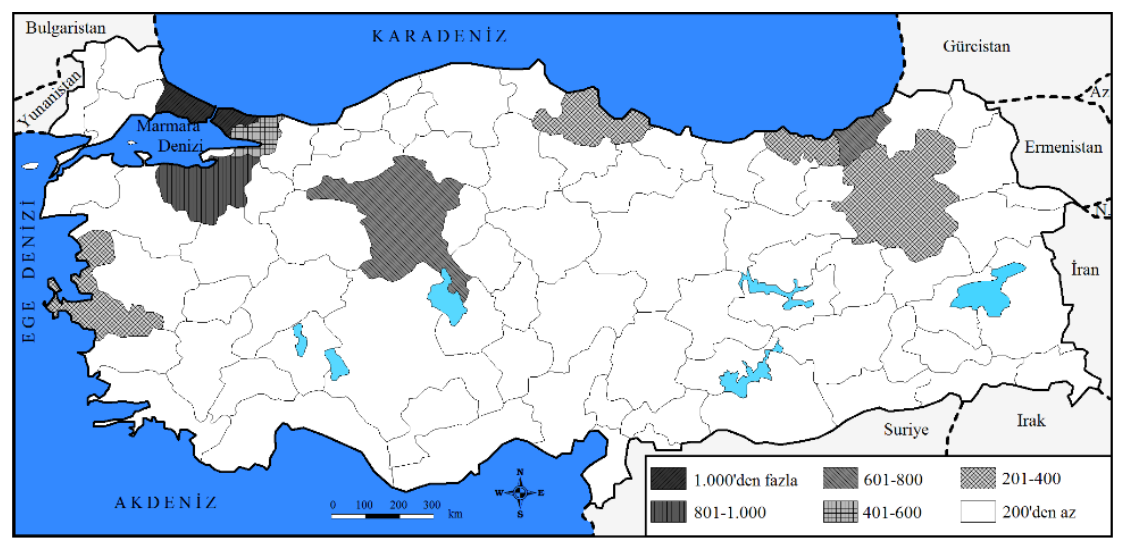

Şekil 7: Artvin ilinden göç eden nüfusun illere göre dağglımı (2012).

Sahada yaşanan göçleri sebeplerine göre incelediğimizde; hem il dışına, hem de diğer illerden Artvin'e yaşanan göçlerde en önde zikredilen sebep, göçlerin hane fertlerinden birine bağımlı olarak gerçekleştiğidir. Ancak bu, göçün temel sebebi hakkında bilgi verici olmayıp diğer sebepleri de kapsayan bir ifadedir. Bu nedenle, sahadan yaşanan göçlerin en önemli sebebi, iş arama/bulma olarak belirtilebilir. Nitekim ilden göç edenlerin yaklaşık \% 21.3'ü, göç etme sebebini bu şekilde belirtmiştir. Ayrıca hanedeki fertlerden birine bağımlı göç içerisinde de, ekonomik amaçlı göçlerin önemli bir yer tutacağını düşündüğümüzde, bu oranın \%30'lara çıkacağı varsayımında bulunmak yerinde olacaktır. Sahadaki insanların göç etmelerindeki ikinci temel sebep ise atamadır (\% 16.0). Geçmişten beri eğitime verilen önemden kaynaklandığını düşündügüumüz sahadaki memur kesimin fazlalığı, bunu ikinci sıraya getirmiştir. Artvin'den göçe neden olan diğer bir sebep ise, eğitimdir (\% 11.9). Bu amaçla yapılan göçler, başta yükseköğretime (üniversite) yönelik olmakla beraber, lise eğitimini il dışında almak isteyenler tarafından da gerçekleştirilmektedir. Bunları, \% 7.7'lik payla evlilik nedeniyle göç edenler takip etmektedir (Tablo 12). 

(2012).

Tablo 11: Artvin ilinin aldığı ve verdiği göçlerin cinsiyet ve yaş yapısına göre dağılımı

\begin{tabular}{|c|c|c|c|c|c|c|c|c|c|c|c|c|}
\hline \multirow{2}{*}{$\begin{array}{l}\text { Yaş } \\
\text { Grupları }\end{array}$} & \multicolumn{6}{|c|}{ Aldığı Göç } & \multicolumn{6}{|c|}{ Verdiği Göç } \\
\hline & Erkek & \%'si & Kadın & $\%$ 'si & Toplam & \%'si & Erkek & \%'si & Kadın & \%'si & Toplam & \%'si \\
\hline $0-14$ & 502 & 47.7 & 550 & 52.3 & 1052 & 14.4 & 617 & 51.9 & 572 & 48.1 & 1189 & 15.6 \\
\hline $15-49$ & 2578 & 52.3 & 2351 & 47.7 & 4929 & 67.7 & 2688 & 49.9 & 2696 & 50.1 & 5384 & 70.7 \\
\hline $50+^{*}$ & 664 & 50.9 & 641 & 49.1 & 1305 & 17.9 & 486 & 46.8 & 553 & 53.2 & 1039 & 13.7 \\
\hline Toplam & 3744 & 51.4 & 3542 & 48.6 & 7286 & 100 & 3791 & 49.8 & 3821 & 50.2 & 7612 & 100 \\
\hline
\end{tabular}

Kaynak: ADNKS verilerinden derlenmiştir.

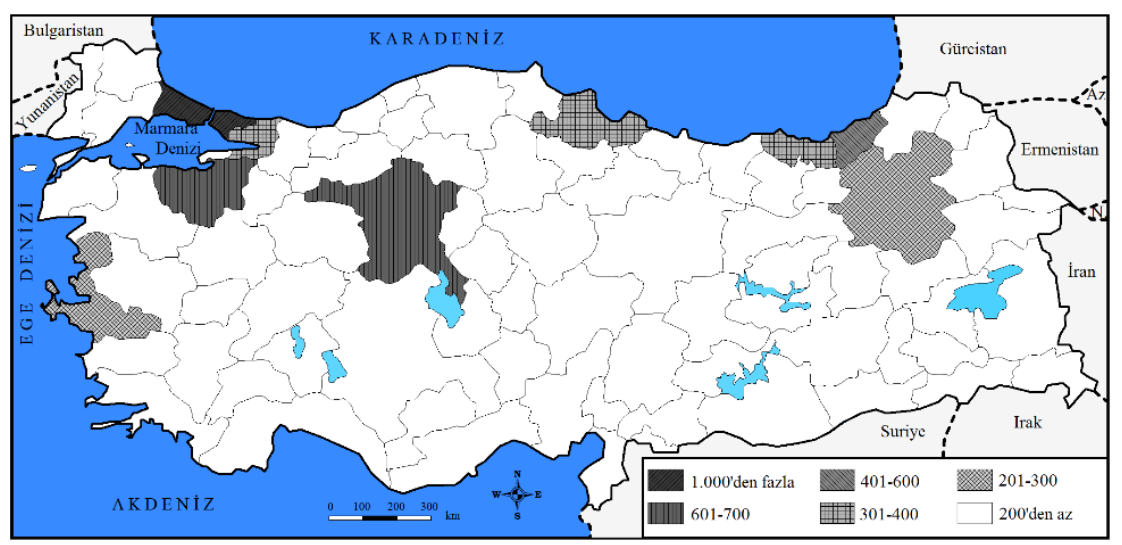

Şekil 8: Artvin iline göç eden nüfusun illere göre dağılımı (2012).

Göç yoluyla Artvin'e gelen 14.374 kişinin göç etme sebeplerini incelediğimizde ise, farklı eğilimler dikkat çekmektedir. Yukarıda belirtilen gerekçelerden dolayı, hanedeki fertlerden birine bağımlı göç göz ardı edildiğinde; göç sebepleri arasında ilk sırada atamanın yer aldığı görülmektedir. İl sınırları içerisinde oldukça fazla kamu çalışanının bulunması, bu sonucu ortaya çıkarmıştır. İkinci sırada yer alan iş arama/bulma (\% 11.3)'yı deprem (\% 9.2) takip etmektedir. Bu sıralamada depremin kendine ön sıralarda yer bulmuş olması, Kocaeli ve çevresinde yerleşmiş olan Artvinlilerden bir kısmının, 1999 yılında yaşanan büyük Marmara Depremi sonucu, geri dönüş yaptığı şeklinde yorumlanabilir. İle yaşanan göçlerin diğer önemli sebeplerini ise, ĕgitim (\% 5.2) ve evlilik (\% 4.7) oluşturmaktadır (Tablo 12). Önceleri Kafkas Üniversitesi'ne bağlı fakültelerin bulunduğu Artvin'de, 2007-2008 eğitim-öğretim yılından itibaren Artvin Çoruh Üniversitesi kurulmuştur. Söz konusu üniversitede, kuruluş yılında öğrenci sayısı 1736 iken, bu sayı yıldan yıla sürekli artarak, günümüzde 4448'e ulaşmıştır (Artvin Çoruh Üniversitesi 20132017 Stratejik Planı, 2012: 16). Bu veriler ışı̆̆ında, Artvin'e göç etme sebepleri arasında, eğitimin oranının artacağı tahmininde bulunmak yanlış olmasa gerekir.

\footnotetext{
* Bu sınıflandırmada 50 yaş ve üzerinin bir tutulması, eskiden çalışmak için göç etmiş olanların, genellikle söz konusu yaşlarda emekli olmalarındandır.
} 
Tablo 12: Artvin ilinin aldığ 1 ve verdiği göçlerin sebeplerine göre dağılımı (2000).

\begin{tabular}{|l|c|c|c|c|c|c|c|c|}
\hline \multirow{2}{*}{ Göç Etme Sebebi } & \multicolumn{3}{|c|}{ Göc Eden Nüfus } & \multirow{2}{*}{$\%$ 'si } & \multicolumn{2}{c|}{ Göç Yoluyla Gelen Nüfus } & \multirow{2}{*}{$\%$ 'si } \\
\cline { 2 - 4 } & Erkek & Kadın & Toplam & & Erkek & Kadın & Toplam & \\
\hline $\begin{array}{l}\text { Hanedeki Fertlerden } \\
\text { Birine Bağımlı Göç }\end{array}$ & 2711 & 4884 & 7595 & 29.3 & 1161 & 2199 & 3360 & 23.4 \\
\hline İș Arama/Bulma & 4305 & 1205 & 5510 & 21.3 & 1432 & 186 & 1618 & 11.3 \\
\hline Atama & 2772 & 1373 & 4145 & 16.0 & 2586 & 750 & 3336 & 23.2 \\
\hline Eğitim & 1877 & 1212 & 3089 & 11.9 & 517 & 231 & 748 & 5.2 \\
\hline Evlilik & 63 & 1934 & 1997 & 7.7 & 27 & 642 & 669 & 4.7 \\
\hline Deprem & 20 & 18 & 38 & 0.1 & 651 & 676 & 1327 & 9.2 \\
\hline Güvenlik & 61 & 24 & 85 & 0.3 & 34 & 10 & 44 & 0.3 \\
\hline Diğer & 2037 & 1133 & 3170 & 12.2 & 2159 & 967 & 3126 & 21.7 \\
\hline Bilinmeyen & 168 & 137 & 305 & 1.2 & 86 & 60 & 146 & 1.0 \\
\hline Toplam & 14014 & 11920 & 25934 & 100 & 8653 & 5721 & 14374 & 100 \\
\hline
\end{tabular}

Kaynak: TÜİK verilerinden derlenmiştir.

Artvin ilinin nüfusu üzerinde önemli oranda değişikliğe neden olan bir diğer göç tipi de, mevsimlik göçlerdir. Söz konusu göçler, araştırma sahası için, kış döneminde il dışında ikamet ettikten sonra, yaz aylarını geçirmek üzere memleketlerine gelen aileler tarafından temsil edilir. Bunların sayılarını tam olarak belirlemek mümkün olmamakla birlikte, on binlerle ifade edilebilecek rakamlara ulaşacağ tahmin edilmektedir. Bir taraftan yörenin yüksek kesimlerinde kış koşullarının ağır geçmesi ile ekonomik kısıtlılıkların ortaya çıkardığı göç etme zorunluluğu; diğer taraftan ise memlekete duyulan özlem, böyle bir tablonun karşımıza çıkmasını sağlamıştır.

\section{Sonuç ve Öneriler}

Artvin ili nüfusu, Cumhuriyet tarihi boyunca genel anlamda artış göstermiştir. Ancak sayım devreleri arasında önemli farklılıkların olduğu da dikkat çekmektedir. $\mathrm{Bu}$ kapsamda 1980 yılına kadar sürekli artan saha nüfusu, bu tarihten sonra da azalma eğilimine girmiştir. $\mathrm{Bu}$ durum üzerinde etkili olan en önemli faktör, göçlerdir. Sahada 1970'li yıllardan sonra yoğunluk kazanan il dışına yaşanan göçler, günümüzde hâlâ devam etmekle beraber; ilin aldığı göç miktarında da önemli oranda artış yaşanmıştır. Ulaşım ve iletişim koşullarında meydana gelen gelişmeler ile eskiden göç etmiş Artvinlilerdeki memleket özleminden kaynaklandığını düşündüğümüz bu durum neticesinde de, aradaki fark azalmış ve ilin toplam nüfusu üzerinde göçlerin etki oranı eskiye nazaran düşmüştür.

Araştırma sahasında 2012 yılı verilerine göre, 167.082 kişi ikamet etmektedir. Ancak söz konusu nüfus, sahaya eşitsiz bir şekilde dağılmıştır. Öncelikle ilin sahip olduğu doğal çevre koşulları ile ilgili olduğunu düşündüğümüz bu durum sonucunda, il arazisinin önemli bir kısmı seyrek nüfusa sahip iken; belli alanlar (kıyı kesimi ile iç kesimlerde akarsu vadileri) ise, daha yoğun bir nüfus barındırmaktadır.

Artvin il nüfusunun yaş gruplarına göre dağılımında, çocuk nüfus oranının düşük olduğu, ancak çalışma çağı ve yaşlı nüfus oranlarında yı̆̆ılmaların meydana geldiği görülmektedir. Bununla birlikte, ilde yeterli istihdam alanı oluşmadığından dolayı, çalışma çağındaki nüfusta il dışına önemli oranda göç yaşanmaktadır. Sahadaki söz konusu potansiyel anlamda dinamik ve üretken nüfusun göç etmesi, il ekonomisi açısından önemli 
bir kayıptır. Bu nedenle, ildeki mevcut istihdam alanlarının kapasitesinin arttırılması ile yeni iş olanaklarının oluşturulması, bu sorunun çözümü açısından yararlı bir tedbir olacaktır. İlin sahip olduğu doğal ve kültürel turistik çekicilikler, bu bakımdan ilde turizm faaliyetlerine, özellikle de kırsal turizme yönelmenin faydalı sonuçlar verebileceği izlenimini uyandırmaktadır.

Sahadaki yaşlı nüfus oranının yüksek olması, bu konuda da çeşitli tedbirlerin alınmasını zorunlu kılmaktadır. Bu bağlamda muhtaç durumdaki yaşlıların bakımını sağlayacak, yeterli sayıda huzur evlerinin yapılması önemli bir adım olabileceği gibi, sağlık kuruluşlarının imkân ve kapasitelerinin arttırılması ve bunlarda özellikle yaşlılarda daha çok görülen hastalık dallarında uzman doktorların çalıştırılması yerinde bir önlem olabilir.

Saha nüfusu niceliksel açıdan yeterli düzeyde gelişim göstermemiş olmasına rağmen, nüfusun yoğun olduğu il ve ilçe merkezlerinde bir takım planlama sorunları ile karşılaşmak da mümkündür. Özellikle yerleşim alanlarının dar olması ve yatırımların düşük düzeyde gerçekleşmesi söz konusu sorunların ortaya çıkasını tetiklemiştir. Bunlar arasında arsa ve konut sıkıntısı başta gelir (Karakuzulu, 2003: 325). Sahanın dağlık ve engebeli yapısı, arsa fiyatlarının dolayısıyla da, konut ve kira fiyatlarının oldukça yüksek seviyelerde seyretmesine neden olmuştur. Benzer bir durum daha geniş alanlara ihtiyaç duyan kamu binaları ile sanayi tesisleri için de geçerlidir. Bu sorunu çözmek amacıyla, özel teşebbüslere bu bölgede yapacakları toplu konutlar için belli ölçülerde vergi muafiyeti uygulanabileceği gibi, TOKİ tarafından da uygun alanlara yeterli kapasitede konut inşa edilmesi yerinde bir önlem olabilir. Zira sahada, TOKİ'nin yaptığı toplu konutlar, sadece Merkez ve Ardanuç ilçelerinde bulunmaktadır. Bunların sayılarının il düzeyinde arttırılmasının, konut ve kira açısından bir rahatlama meydana getireceğini ifade etmek mümkündür.

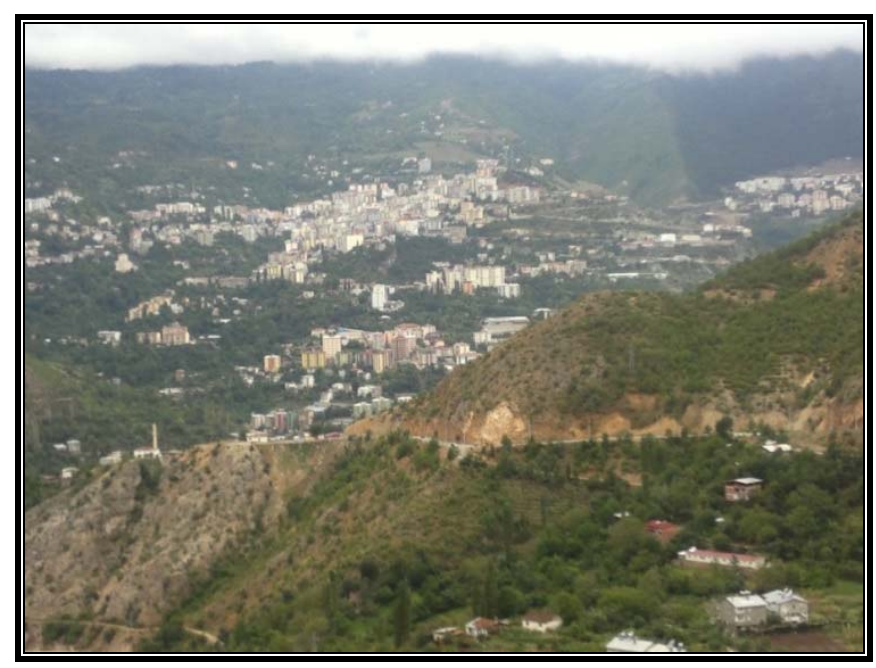

Fotoğraf 1: Artvin kenti, Çoruh vadisinin kuzeydoğuya bakan yamacında kurulmuştur. 
Artvin İlinde Nüfusun Başlıca Özellikleri

Sahadaki şehir ve kasabalarda var olan arsa sıkıntısı, cadde ve kaldırımların dar olması, park ve yeşil alan kısıtlılığı, şehir içi ulaşım güçlükleri gibi pek çok sorunu da beraberinde getirmiştir (Koday ve Erhan, 2010: 229). Özellikle eğimli bir vadi yamacında kurulmuş olan Artvin kentinde (Fotoğraf 1) çok daha bariz olan bu durum, şehirsel gelişim açısından kısıtlamalara neden olmaktadır. Bu nedenle de, Artvin şehrinin yerleşim alanı, vadinin diğer yamacına doğru kaymak zorunda kalmıştır. Yatay gelişimin sınırlı ölçüde gerçekleşebildiği bu tür yerleşmelerde, dikey gelişim ön plana çıkmaktadır. Ancak bu durumda da, heyelan riskinin yüksek olduğu bölgede, yaşanan bu afetler daha fazla kayba neden olabilmektedir. Bu kapsamda, doğal koşulların uygulamada zorluklar çıkaracağ aşikâr olmakla beraber, çok yönlü olarak ele alınmış ve yörenin topoğrafyasına uygun planlar hazırlanmalı ve bunlar tatbik edilmeye çalışılmalıdır (Koday, 1991: 101).

Sonuç olarak, sahayı ilgilendiren herhangi bir yatııı için, nüfusun sayısı kadar çeşitli özelliklerinin de göz önünde tutulması faydalı olacaktır. Ancak bu noktada dikkat edilmesi gereken önemli bir ayrıntı da, il nüfusundaki mevsimsel değişimdir. Kimi ilçelerde nüfusun neredeyse iki katını bulduğu yaz döneminde, il genelinde ise, belki de elli bini aşan bir artıştan bahsedilebilir. Bu nedenle, il için yapılacak proje ve yatırımlarda bu durumun da göz önünde tutulması, belirtilen bazı sıkıntıların ortadan kalkmasına ve birtakım yeni sorunların oluşmasının engellenmesine vesile olabilir. 


\section{KAYNAKÇA}

Artvin Çoruh Üniversitesi 2013-2017 Stratejik Planı (2012), http://www.artvin.edu.tr /strateji/dosyalar/Stratejik_Plan_2013 2017.pdf, Erişim Tarihi: 16.12.2013.

Çapa, M., 2012, Milli Mücadele Döneminde Artvin, Karadeniz İncelemeleri Dergisi, Cilt: 7, Say1: 13 (http:// asosindex.com Erișim Tarihi: 04.12.2013).

Demirel, M., 2009, Artvin ve Batum Göçmenleri (1877-1878 Osmanlı-Rus Savaşıı'ndan Sonra), Atatürk Üniversitesi Türkiyat Araştırmaları Enstitüsü Dergisi, Sayı:40, Erzurum.

Demirel, M., 2010, Yusufeli Tarihi, FSF Printing House Matbaacılık, İstanbul.

DíE, 2001, 2000 Genel Nüfus Sayımı, Nüfusun Sosyal ve Ekonomik Nitelikleri, Artvin İli Devlet İstatistik Enstitüsü Matbaası, Yayın No: 2489, Ankara.

Doğanay, H., 1986, Trabzon'da Nüfus Hareketleri ve Göçler, Atatürk Üniversitesi FenEdebiyat Fakültesi Araştırma Dergisi, Sayı: 15, Erzurum.

Doğanay, H., 1997, Türkiye Beşeri Coğrafyası, Milli Eğitim Bakanlığı Yayınları, Yayın No:2982, Bilim ve Kültür Eserleri Dizisi: 877, Eğitim Dizisi:10, Milli Eğitim Basımevi, İstanbul.

Doğanay, H., Özdemir, Ü., Şahin, F. İ., 2011, Genel Beşeri ve Ekonomik Coğrafya, Pegem Akademi Yayınevi, Ankara.

Ersoy, O., 1964, Bir Ingiliz Konsolosunun 1846 Yllinda Erzurum'dan Kars'a Seyahati, Tarih Araştırmaları Dergisi, Cilt: 2, Sayı: 2, Ankara.

Gök, Y., 2010, Tarihi Süreç İçerisinde Yusufeli Nüfusu, Geçmişten Geleceğe Yusufeli Sempozyumu Bildirileri, Yusufeli Belediyesi Yayını, İstanbul.

Işık, Ş.,1997, Güneydoğu Anadolu Bölgesinde Nüfusun Miktarı ve Yapısal Özellikleri, Ege Coğrafya Dergisi, Sayı: 9, İzmir.

Karakuzulu, Z., 2003, Doğu Karadeniz Bölümü’nün Topoğrafya Özelliklerinden Kaynaklanan Nüfus Dă̆gllş Sorunları, Doğu Karadeniz Bölgesi’nde Kırsal Alanda Ulaşım, Yerleşim Sorunları ve Çözümleri Sempozyumu, Bildiriler Kitabı (18-20 Aralık), Trabzon.

Koca, H.,2005, Kuruluşu-Gelişmesi ve Fonksiyonel Özellikleri Yönünden Dörtyol Şehri, Aktif Yayınevi, İstanbul.

Koday, Z., 1991, Borçka İlçe Merkezi'nin Coğrafi Etüdü, Atatürk Üniversitesi Sosyal Bilimler Enstitüsü, Yayımlanmamış Yüksek Lisans Tezi, Erzurum.

Koday, S., Erhan, K., 2010, Çoruh Vadisinde Nüfusun Dağıllşıl, Atatürk Üniversitesi Sosyal Bilimler Enstitüsü Dergisi, Cilt: 14, Sayı: 2, Erzurum.

Okçu, N., Akdağ, H., 2010, Salnâme-i Vilâyet-i Erzurum (1287/1870-1288/18711289/1872-1290/1873) Erzurum İl Yıllı̆̆ı, Atatürk Üniversitesi Yayınları No: 984, 
İlahiyat Fakültesi Yayınları No:13, Araştırma Serisi No:10, Zafer Form Ofset Matbaacilık, Erzurum.

Özgür E. M., 1998, Türkiye Nüfus Coğrafyası, GMC Basım Yayın, Ankara.

Özgür, E.M., 2010, Nüfusun Coğrafi Analizi, Ankara Üniversitesi Dil ve Tarih-Coğrafya Fakültesi Ders Notları, Ankara (http://www.geography.humanity.ankara.edu.tr/ ders notu/COG407 ders_notu_1011.pdf,Erişim tarihi: 08.12.203).

Özdemir, H., 2001, Artvin Tarihi, Ajans Ege Matbaacılık, Ankara.

Tandoğan, A., 1998, Demografik Temel Kavramlar ve Türkiye Nüfusu. Eser Ofset Matbaacilık, Trabzon.

Tanoğlu, A., 1969, Nüfus ve Yerleşme, İstanbul Üniversitesi Yayınları No: 1183, Edebiyat Fakültesi Coğrafya Enstitüsü Yayınları No:45, Taş Matbaası, İstanbul.

Tıraş, M., 1997, Yusufeli’nde Nüfus Hareketleri, Atatürk Üniversitesi Fen-Edebiyat Fakültesi Edebiyat Bilimleri Araştırma Dergisi, Sayı: 24, Erzurum.

Trabzon Vilayet Salnamesi, 1869 (Cilt 1), Trabzon İli ve İlçeleri Eğitim, Kültür ve Sosyal Yardımlaşma Vakfı, Haz. Kudret Emiroğlu, Özkan Matbaacılık, Ankara.

Trabzon Vilayet Salnamesi, 1872 (Cilt 4), Trabzon İli ve İlçeleri Eğitim, Kültür ve Sosyal Yardımlaşma Vakfi, Haz. Kudret Emiroğlu, ETAM Matbaacılık, Ankara.

Trabzon Vilayet Salnamesi, 1876 (Cilt 8), Trabzon İli ve İlçeleri Eğitim, Kültür ve Sosyal Yardımlaşma Vakfi, Haz. Kudret Emiroğlu, ETAM Matbaacılık, Ankara.

Tuncel, M., 1991, Türkiye Diyanet Vakfı İslâm Ansiklopedisi-Artvin Maddesi, Ali Rıza Baskan Güzel Sanatlar Matbaası, Cilt: 3, İstanbul.

TÜİK, 2005, 2000 Genel Nüfus Sayımı Göç İstatistikleri, Türkiye İstatistik Kurumu Matbaas1, Yayın No: 2976, Ankara.

TÜİK, Seçilmiş Göstergelerle Artvin 2012.

Tümertekin, E., Özgüç, N., 2011, Beşeri Coğrafya, İnsan-Kültür-Mekan, Çantay Kitabevi, İstanbul.

Zaman, S., Coşkun, O., 2008, Rize İlinin Nüfus Coğrafyası Özellikleri ve Bunları Etkileyen Etmenler Üzerine Bir İnceleme, Atatürk Üniversitesi Sosyal Bilimler Enstitüsü Dergisi, Cilt: 12, Sayı: 2, Erzurum. 